\title{
A CLINICO-PATHOLOGICAL ANALYSIS OF CHONDROBLASTOMA
}

\section{Orthopaedics}

Dr. Ragini Kumari

MBBS, M.D. (Patho.), Tutor, Department of Pathology, Darbhanga Medical College, Laheriasarai, Bihar.

Dr. Kunal

Shankar*

MBBS, M.S. (Orthopaedics) [Hons.], Senior Resident, Department of Orthopaedics, Darbhanga Medical College \& Hospital, Laheriasarai, Bihar.*Corresponding Author

\section{Dr. [Prof.] Ajit} Kumar Chaudhary

MBBS, M.D. (Patho.), Professor and Head of Department, Department of Pathology, Dr. Debarshi Jana

Darbhanga Medical College, Laheriasarai, Bihar.

Young Scientist (DST) Institute of Post-Graduate Medical Education and Research, A.J.C. Bose Road, Kolkata-700020, West Bengal, India.

\section{ABSTRACT}

Objective: To determine the clinico-pathological and histological features of Chondroblastoma (CB). Place of study: Department of Pathology associated with Orthopaedics Department, Darbhanga Medical College and Hospital, Laheriasarai, Bihar. Methodology: The histological slides of all reported cases of CB were retrieved and reviewed for morphological features. Clinical features were noted from surgical pathology reports. Frequency of features was noted.Results: Sixty one cases of CB were identified. Pain was the most common presenting symptom. The age ranged from 10 to 38 years (mean $20 \pm 1.98$ years; M: F 2.5:1) with 61\% patients in the second decade of life. Forty six cases occurred in long tubular bones; distal femur being most common site. Metaphysis, clavicle, temporal bone and metacarpal were also involved. Histologically, all CBs were composed of round to polygonal cells and scattered osteoclast-type multinucleated giant cells and majority had hemosiderin pigment. Chickenwire calcifications and coarse calcifications were seen in $85 \%$ and $26 \%$ of cases respectively. A spindle cell component was seen in $54 \%$ of cases. ABC-like areas were seen in 10 cases. Mitosis ranged from 1 to 6/10 HPFs. Recurrence was seen in 2 cases. Recurrent tumor showed similar morphology when compared with the initial tumor. Conclusion: CB is a benign tumor but has potential for recurrence. Males are more affected, second decade is more common and distal femur is most common site. Metaphysis, clavicle, temporal bone and metacarpal were the rare sites of CB. Histological features predictive of recurrence were not separately identified.

\section{KEYWORDS}

Chondroblastoma. Bone tumors. Chicken Wire Calcification. Recurrence

\section{INTRODUCTION}

Chondroblastoma $(\mathrm{CB})$ is a rare benign cartilage tumor accounting for $<1 \%$ of all bone tumors. It occurs in the second decade of life, typically in the epiphysis of long tubular bones such as humerus, femur and tibia with a predilection for men. This tumor arises from secondary centers of ossification, suggesting possible origin from cartilage growth plates. Kolodny for the first time described this tumor as a variant of giant cell tumor in 1927, which a year later was named as calcifying giant cell tumor by Ewing. It was termed epiphyseal chondromatous giant cell tumor by Codman in 1931 .

Finally, the term benign chondroblastoma was introduced by Jaffe and Lichtenstein in 1942. They described this tumor as a distinct clinicopathological entity different from giant cell tumor with a predilection for humerus.

The objective of this study was to report the spectrum of morphological features seen on a cohort of chondroblastoma cases with any histological features predictive of recurrence.

\section{MATERIALAND METHODS}

This study was conducted at Department of Pathology association with Orthopaedics, Darbhanga Medical College and Hospital, Laheriasarai, Bihar. Total 61 cases of chondroblastoma selected in Histopathology, at $\mathrm{DMCH}$, Laheriasarai, Bihar.

Morphological features were noted for the following parameters; nuclear grooves/ indentation, chicken-wire calcifications, chondroid and osteoid matrix, multinucleated giant cells, hemosiderin pigment, Aneurysmal bone cyst component, spindle cells, necrosis, mitosis and invasion. Mitotic figures were counted in four different sets of $10 \mathrm{HPFs}$ in most cellular areas and selecting the highest count. Radiological correlation was made in most of the cases at the time of diagnosis. Clinical features of these cases were obtained from the surgical pathology reports.

Data were entered and analysis done by using SPSS version 20 . Descriptive statistics like mean and standard deviation was calculated for continuous variables, whereas frequency and percentage was calculated for categorical variables.

\section{RESULTS}

Forty four males and 17 females were included in this study with a male to female ratio of $2.5: 1$. The age ranged from 10 to 38 years (mean $20 \pm 1.98$ years; median 19 years). Thirty seven $(61 \%)$ of the patients were in the second decade and $21(34 \%)$ patients in the third decade. Only 3 patients were in the fourth decade.

Pain was the most common presenting symptom and was present in 31 $(60 \%)$ cases with duration ranging from 3 to 120 months. History of swelling was present in $15(24.5 \%)$ of the cases. A suspicion of CB was raised by the clinician in $8(13.1 \%)$ cases; giant cell tumor and bone cyst in 5 and 3 of the cases respectively. No history was provided in 9 $(14.7 \%)$ of cases.

Forty six (75.4\%) tumors were located in long tubular bones; distal femur being most common site seen in $13(21.3 \%)$ cases followed by proximal tibia and proximal humerus. Rare locations included clavicle, temporal bone and metacarpal seen in one caseeach (Figure 1). Site was not provided in $5(11 \%)$ cases. The size of biopsy material ranged from 1 to $9 \mathrm{~cm}$ (mean $4 \pm 1.98 \mathrm{~cm}$; median $3.5 \mathrm{~cm}$ ).

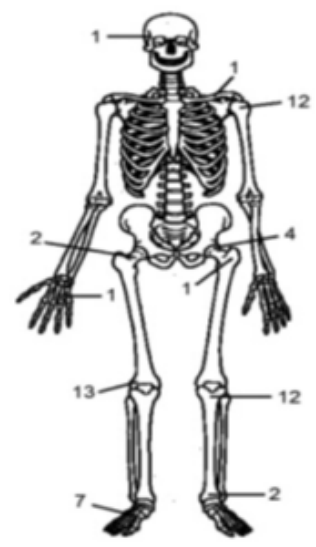

Figure 1: Skeletal distribution of the 56 chondroblastomas in our study. Site was not known in 5 cases. 
Histologically, all CBs were composed of round or polygonal cells with indented or grooved nuclei and eosinophilic cytoplasm with usually well-defined cell borders. Scattered osteoclast type multinucleated giant cells were seen in all cases, present singly dispersed between the tumor cells or in small groups. These cells were generally small to medium sized, with irregular cell contours containing $<20$ nuclei (Figure 2A). The characteristic chicken-wire calcifications were seen in $52(85 \%)$ and coarse calcifications in 16 $(26 \%)$ cases (Figures $2 \mathrm{~B}$ and C). Hemosiderin pigment was seen in 47 $(77 \%)$ cases. Mostly it was present in the cytoplasm of macrophages, but in some cases deposited in the tumor cells (Figure 2D). A spindle cell component was seen in $33(54 \%)$ cases and in $11(18 \%)$ of cases, it was fibromyxoid resembling chondromyxoid fibroma (Figure 3A). Chondroid and osseous metaplasia was seen in $32(52 \%)$ and $52(85 \%)$ cases respectively (Figure 3B)

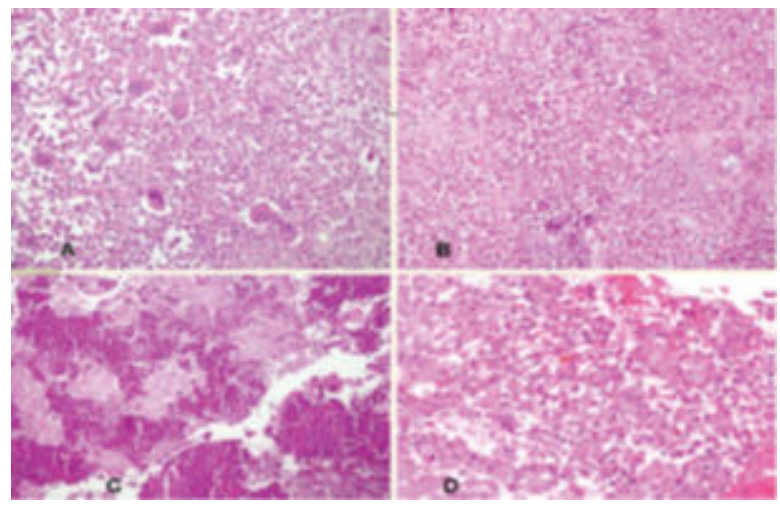

Figure 2

Figure 2: Sheets of mononuclear cells with scattered multinucleated giant cells is a typical example of chondroblastoma (A). Characteristic chicken wire calcifications surrounding the individual cells $(B)$. Heavy mineralization in chondroblastoma (C). Hemosiderin in the cytoplasm of tumor cells (D) [H \&E, 200x].

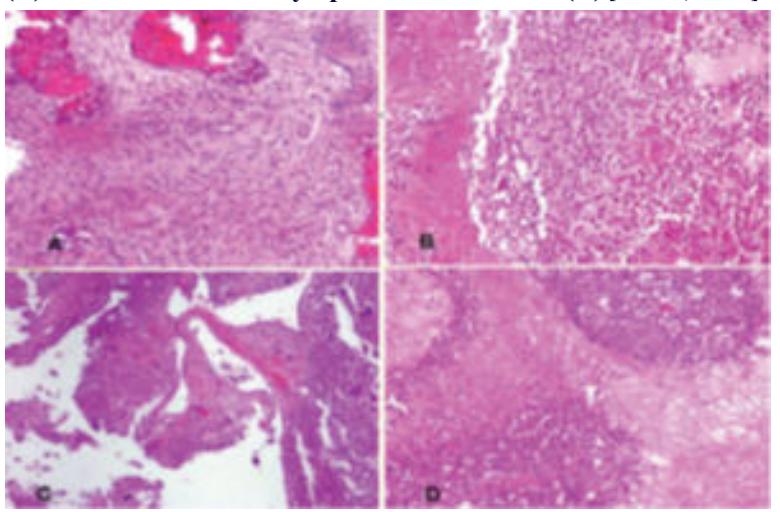

Figure 3: Spindle cells in a myxoid background. These cells lacked nuclear grooves of the typical mononuclear cells (A). Chondroblastoma with both osseous [left] and chondroid matrix [right] (B). ABC like areas in chondroblastoma (C). Palisading type necrosis in chondroblastoma (D) [H\&E,200x].

True hyaline cartilage was not seen. The osseous metaplasia was both immature/woven and mature. Ten $(16 \%)$ had ABC-like areas (Figure $3 \mathrm{C})$. Majority of the cases having $\mathrm{ABC}$ component were of long tubular bones and in the third and fourth decade. Two cases of cuboid and a single case of clavicle also had it. Focal aggregates of foamy histiocytes were seen in 2 cases.

The mitotic figures ranged from 1 to $6 / 10$ HPFs (mean $2.1 \pm 1.51$, median $2 / 10$ HPFs). No atypical mitosis was seen. Focal necrosis was seen in $10(16 \%)$ cases. The necrosis was associated with calcification, but 4 cases had genuine palisading necrosis (Figure 3D). Four (6.5\%) cases showed adjacent bone invasion. No vascular invasion or soft tissue extension was noted.

Special stains (PAS with diastase and reticulin stain) were applied in all cases. Abundant glycogen was seen in the cytoplasm of tumor cells and reticulin surrounding individual cells was noted. S100 was performed in 15 cases and showed positivity in all cases. Radiographic correlation was made in most cases at the time of diagnosis.

Follow-up was available in 20 cases (33\%). The duration ranged from 2 to 71 months. Recurrence was seen in $2(10 \%)$ cases; one in case of proximal humerus and one in the talus. Recurrences were developed after a followup of 8 to 12 months. The recurrent tumor showed similar morphology when compared with the initial one.

No histological features such as mitosis, necrosis, and invasion or $\mathrm{ABC}$ component were associated with recurrence risk. No metastases were seen. Main outcome findings are summarized in Table I.

Table 1 : Main outcome findings

\begin{tabular}{|c|c|}
\hline Parameter & Frequency (\%) \\
\hline $\begin{aligned} \text { A) Clinical features } \\
\text { : Male } \\
\text { : } \text { Female } \\
\text { : History of pain } \\
\text { - Clinical suspicion of chondroblastoma }\end{aligned}$ & \begin{tabular}{|l|}
$44(72 \%)$ \\
$17(28 \%)$ \\
$31(60 \%)$ \\
$15(24.5 \%)$ \\
$8(13 \%)$ \\
$46(75.4 \%)$ \\
$2(10 \%)$
\end{tabular} \\
\hline \begin{tabular}{|l} 
B) Histological features \\
- Nuclear grooves \\
- Osteiclast type multinucleated giant cells \\
- Hemosiderin pigment \\
- Spindle cell areas \\
- Ohondroid areas \\
- Aneous metaplasia \\
- Necrosis
\end{tabular} & $\begin{array}{l}61(100 \%) \\
61(100 \%) \\
52(85 \%) \\
47(77 \%) \\
33(54 \%) \\
32(52 \%) \\
52(85 \%) \\
10(16 \%) \\
10(16 \%)\end{array}$ \\
\hline
\end{tabular}

\section{DISCUSSION}

This retrospective study shows the varied clinical features and wide morphologic spectrum of chondroblastoma.

As indicated in the previous studies, this tumor is invariably presents with history of pain in the involved area in $83 \%$ to $100 \%$ of the cases with duration ranging from 2 weeks 11 to 8 years. A history of pain was present in $60 \%$ of our patients and one patient had 10 years history of pain. The other symptoms described were local swelling, 12 limitation of movements, 12 joint effusion, and limping. The age ranged from 5 to 70 years, but the peak age was second decade in all studies including the present. The male to female ratio was $1.5: 1$ to $2: 1$, and $2.5: 1$ in this series.

Chondroblastoma preferentially involves the epiphysis of long tubular bones in majority of the cases and $82 \%$ cases in this series were located in the long tubular bones. The commonest site of involvement is variable in different studies, but proximal tibia was seen in majority of the series, and distal femur in this study, while proximal femur and proximal humerus was noted in other series. Metaphyseal chondroblastoma is rare.

Two tumors in this series were located in the femur neck, with one presenting with pathological fracture. The other less involved sites are bones of foot, patella and craniofacial bones. Seven cases in this series were involving the foot bones. One case in this series was located in the clavicle, which is a very rare event and only 2 cases are previously reported. Involvement of temporal bone is uncommon and seen in one of our case. Involvement of metacarpal is even rarer and to the best of authors' knowledge only 8 cases have been published.

Histologically, chondroblastoma is composed of mononuclear cells with nuclear grooves and scattered osteoclast type multinucleated giant cells. Chicken-wire calcification is delicate surrounding around individual tumor cells. It is virtually pathognomonic for chondroblastoma, but is not present in cases subjected to decalcification, hence not necessary for the diagnosis. In various studies, these were noted in $35 \%$ to $52.8 \%$ of the cases and $85 \%$ in this study. Osteoclast type multinucleated giant cells are present in every case.

Chondroid and osseous matrix is variably seen and the former was noted in $95 \%$ of the cases in one study and $52 \%$ in this series and the latter in $85 \%$ of our cases.

A spindle cell component with foci resembling chondromyxoid 
fibroma is another feature noted in the previous studies, and in this as well. Mitotic activity was none to $>4$ in one study; however, no atypical mitosis was noted. Mitosis were seen in $87 \%$ of these cases and ranged from 1-6/10 HPFs. More than 4 mitoses were seen in 7.5\% of these cases. Necrosis was noted in $14 \%$ to $41 \%$ of the reported cases and we noted in $16 \%$ of the cases. A secondary aneurismal bone cyst was associated with chondroblastoma in $10 \%$ to $38 \%$ of cases and $16 \%$ in this study.

Recurrence rate of chondroblastoma ranged from $5.7 \%$ to $32 \%$ in the reported cases. The association of an $\mathrm{ABC}$ component was initially thought to be a risk factor for recurrence, but this was not confirmed by others 14 and here as well. Histological features of malignancy such as mitosis, necrosis, atypia were not associated with recurrence. Similar is also noted in the present series.

\section{CONCLUSION}

$\mathrm{CB}$ is a benign tumor but has the potential for recurrence. Males were more affected and proximal tibia was the most common site. Metaphysis, clavicle, temporal bone and metacarpal are rare sites of CB. No histological features predictive of recurrence are seen.

Chicken-wire calcification is pathognomonic but not present in cases subjected to decalcifications. Therefore, it is very important not to lose this useful diagnostic feature by decalcifying an epiphyseal tumor from a young patient.

\section{REFERENCES}

1. Bloem JL, Mulder JD. Chondroblastoma: a clinical and radiological study of 104 cases. Skeletal Radiol 1985; 14:1-9.

2. Chandu de Silva MV, Reid R. Chondroblastoma: varied histologic appearance, potential diagnostic pitfalls, and clinicopathologic features associated with local recurrence. Ann Diag Pathol 2003; 7:205-13.

3. Codman EA. Epiphyseal chondromatous giant cell tumors of the upper end of the humerus. Surg Gynec Obstet 1931; 52:543-8.

4. Crim JR, Gold RH, Mirra JM, Gebhardt MC, Mankin HJ. Chondroblastoma of the femur with an aneurysmal bone cyst. Skeletal Radiol 1992; 21:403-5.

5. Dahlin DC, Ivins JC. Benign chondroblastoma: a study of 125 cases. Cancer 1972; 30:401-13.

6. Edel G, Uveda Y, Nakanishi J, Brinker KH, Roessner A, Blasius S, et al. Chondroblastoma of bone, a clinical, radiological, light and immunohistochemical study. Virschows Archiv A Pathol Anat 1992; 421:355-66.

7. Ewing J. The classification and treatment of bone sarcoma, in report of the International Conference on Cancer. Bristol: John Wright and Sons; 1928.

8. Fletcher CDM, Unni KK, Mertens F, (eds). World Health Organization classification of tumours pathology and genetics tumours of soft tissue and bone. Lyon: IARC Press; 2013.

9. Hatano M, De Donato G, Falcioni M, Sanna M. Chondroblastoma of the temporal bone. Acta Otolaryngol 2001; 131:890-5.

10. Huvos AG, Marcove RC. Chondroblastoma of bone. A critical review. Clin Orthop 1973;95:300-12.

11. Inwards CY, Unni KK. Bone tumours. In: Mills SE, Carter D, Greenson JK, Reuter VE, Stoler MH. editors. Sternberg's diagnostic surgical pathology. Philadelphia, PA: Lippincott Williams \& Wilkins; 2010; p. 236-84

12. Jaffe HL, Lichtenstein L. Benign chondroblastoma of bone. A reinterpretation of the socalled calcifying or chondromatous giant cell tumour. Am J Pathol 1942; 18:969.

13. Kolodney A. Bone sarcoma: the primary malignant tumours of bone and the giant cell tumor. Surg Gynec Obstet 1927; 44:1-214.

14. Konishi E, Okubo T, Itoi M, Katsumi Y, Murata H, Yanagiswa A. Chondroblastoma of trapezium with metacarpal involvement. Orthopedics 2008;31:395.

15. Kudo T, Okada K, Hirano Y, Sageshima M. Chondroblastoma of a metacarpal bone mimicking an aneurysmal bone cyst: a case report and a review of literature. Tohoku J Exp Med 2001;194:251-7.

16. Kurt AM, Unni KK, Sim FH, McLeod RA. Chondroblastoma of bone. Hum Pathol 1989;20:965-76

17. Maheshwari AV, Jelinek JS, Song AJ, Nelson KJ, Murphey MD, Henshaw RM. Metaphyseal and diaphyseal chondroblastomas. Skeletal Radiol 2011; 40:1563-73.

18. Ramappa AJ, Lee Francis YL, Tang P, Carlson JR, Gebhardt MC, Mankin HJ. Chondroblastoma of bone. J Bone Joint Surg 2000; 82:1140-5.

19. Sailhan F, Chotel F, Parot R. Chondroblastoma of bone in a pediatric population. J Bone Joint Surg Am 2009; 91:2159-68.

20. Salzer M, Salzer-kuntschik M, Kretschmer G. Das benign chondroblastom. Arch Orthop Unfallchir 1968; 64:229-44.

21. Schajowicz F, Gallardo H, Aires B. Epiphyseal chondroblastoma of bone: a clinicopathological study of sixty-nine cases. J Bone Joint Surg 1970; 52:205-25.

22. Springfield DS, Capanna R, Gherlinzoni F, Picci P, Campanacci M. Chondroblastoma; a review of seventy cases. J Bone Joint Surg 1985; 67:748-54.

23. Turcotte RE, Kurt AM, Sim FH, Unni KK, McLeod RA. Chondroblastoma. Hum Pathol $1993 ; 24: 944-9$ 